\title{
Efficacy of Bronchial Brush Cytology and Bronchial Washings in Diagnosis of Non Neoplastic and Neoplastic Bronchopulmonary Lesions
}

\author{
Neoplastik ve Nonneoplastik Bronkopulmoner Lezyonların Tanısında \\ Bronş Fırçalama ve Yıkama Materyallerinin Etkinliği
}

\author{
Monisha CHOUDHURY, Smita SINGH, Savita AGARWAL
}

Department of Pathology, Lady Hardinge Medical College, NEW DELHI, INDIA

\section{ABSTRACT}

Objective: The present study is based on the cytologic evaluation of bronchial brushings for the diagnosis of non neoplastic and neoplastic bronchopulmonary lesions and relation of the cytologic findings with clinical diagnosis and histopathologic examination wherever possible.

Material and Method: 35 symptomatic patients were selected on whom bronchoscopy was done. Bronchial brushing was performed using straight brushes and bronchial washing specimens were collected after brushing samples. Smears were stained by PAP, H\&E, and Giemsa in all the cases while PAS and Ziehl Neelsen stainings were done in selected cases. Endobronchial biopsy was performed using a flexible long biopsy forceps.

Results: The age of the patients varied from 18 to 88 years, and the male:female ratio was 3.3:1. Carcinoma was diagnosed in $21(60 \%)$ out of total 35 cases on bronchial biopsy and the remaining 14 cases (40\%) showed inflammatory, tuberculous or no significant pathology. Bronchial washing showed 10 true positive, 10 true negative, 4 false positive and 11 false negative cases whereas bronchial brushing showed 17 true positive, 12 true negative, 2 false positive and 4 false negative cases as confirmed on biopsy. Bronchial brushing showed good sensitivity (80.9\%) and specificity (85.7\%) compared to bronchial washing which had sensitivity of $47.6 \%$ and specificity of $71.4 \%$.

Conclusion: These findings attempted to confirm the concept that pulmonary cytology has improved to the point that its sensitivity is high enough to justify its use as a definitive diagnostic tool in those cases in which tissue diagnosis is not possible.

Key Words: Cytology, Pulmonary neoplasms, Pulmonary abscess, Tuberculosis, Chronic bronchitis

\begin{abstract}
ÖZ
Amaç: Neoplastik ve non-neoplastik akciğer lezyonlarında bronş fırçalama materyalinin sitolojik değerlendirme sonuçlarını klinik tanı ve histopatolojik inceleme sonuçları ile karşılaştırmak.

Gereç ve Yöntem: Bronkoskopi yapılan 35 semptomatik olgu değerlendirmeye alındı. Rutin bronş fırçalaması ve ardından bronş yıkama sıvısı alındı. Yaymalar PAP, H\&E ve Giemsa ile, gereken olgularda ek olarak PAS ve Ziehl Neelsen ile boyandı. Ayrıca, biyopsi forsepsi ile endobronşial biyopsi alındı.

Bulgular: Olguların yaşı 18-88 arasında değişiyordu ve erkek:kadın oranı 3.3:1'di. 35 olgunun 21'inde (\%60) karsinom saptanırken, diğer 14 olguda (\%40) enflamatuvar lezyon, tüberküloz veya patoloji olmadığı saptandı. Bronş iğne biyopsisi ile değerlendirildiğinde bronş yıkama materyali 10 gerçek pozitif, 10 gerçek negatif, 4 yanlış pozitif, 11 yanlış negatif sonuç verirken, bronş fırçalama materyali 17 gerçek pozitif, 12 gerçek negatif, 2 yanlış pozitif, 4 yanlış negative sonuç verdi. Bronş fırçalaması iyi duyarlılık $(\% 80,9)$ ve özgüllük $(\% 85,7)$ gösterirken, bronş yıkamasında duyarlılık \%47,6 ve özgüllük \%71,4 düzeyinde kaldı.
\end{abstract}

Sonuç: Sonuçlar, doku tanısı yetersiz olduğunda akciğer sitolojisinin tanısal olarak kullanılabilecek duyarlılığa sahip olduğu görüşünü desteklemektedir

Anahtar Sözcükler: Sitoloji, Akciğer tümörleri, Akciğer apsesi, Tüberküloz, Kronik bronşit

Correspondence: Savita AGARWAL

Department of Pathology, Lady Hardinge Medical College,

NEW DELHI, INDIA

E-mail: savvymedico@gmail.com Phone: +0525 2232985 


\section{INTRODUCTION}

The flexible fibreoptic bronchoscope enables several investigations to be carried out but selective bronchial brushing seems to be the most rewarding as the results obtained by brushing are often superior to those obtained by bronchial washings, biopsy or sputum examination, especially for lesions located distal to segmental bronchi. Studies done using bronchial brushing for cytodiagnosis of lung cancer have emphasised its high accuracy rate in the evaluation of neoplastic and non neoplastic pulmonary lesions (1-6). The present study is based on the cytologic evaluation of bronchial brushings for the diagnosis of non neoplastic and neoplastic bronchopulmonary lesions and correlates the cytologic findings with the clinical diagnosis and histopathologic examination wherever possible.

\section{MATERIAL and METHODS}

This study was carried out prospectively in the department of Pathology LHMC, New Delhi. Thirty-five symptomatic patients were selected for the present study. These patients had one or more of the following features; growing peripheral lesion on chest ray, positive sputum cytology, and clinical symptom refractory to medication or visible endobronchial mass.

Detailed clinical history, physical examination, hemogram, chest X-ray and bronchoscopy was performed on all 35 cases.

USG guided transthoracic fine needle aspiration cytology (FNAC) was done for peripherally situated lesions.

Bronchoscopy was performed through the transnasal approach, using an Olympus BF- 2TR fibreoptic bronchoscope.

Bronchial brushing (BB) was performed using straight brushes. After the sampling brush was smeared on 5-6 clean slides, these were fixed in 95\% ethyl alcohol for PAP, H\&E and PAS staining and absolute methanol for Giemsa staining. Bronchial washings were collected after brushing samples. Smears were prepared using sediments and stained by Pap, H\&E, Giemsa and Ziehl Neelsen stain. The remaining material was used for cell block preparation wherever possible.
Endobronchial biopsy was performed using a flexible long biopsy forceps and tissue bits were fixed in 10\% formalin and processed for histopathological examination.

\section{OBSERVATION}

The study group consisted of 35 cases selected on the basis of clinical, radiological and bronchoscopic findings. The age of the patients varied from 18 years to 88 years, and the M:F ratio was 3.3:1. Twenty-five cases $(71.4 \%)$ were smokers and 10 were non smokers with a smokers to nonsmokers ratio of 2.5:1.

Carcinoma was diagnosed in $21(60 \%)$ out of total 35 cases on bronchial biopsy and the remaining 14 cases (40\%) showed inflammatory, tuberculous or no significant pathology (Table I).

Bronchial washing showed 10 true positive (TP), 10 true negative (TN), 4 false positive (FP) and 11 false negative (FN) cases whereas bronchial brushing showed $17 \mathrm{TP}, 12$ $\mathrm{TN}, 2 \mathrm{FP}$ and $4 \mathrm{FN}$ cases as confirmed on biopsy (Table II).

Bronchial brushing showed good sensitivity $(80.9 \%)$ and specificity $(85.7 \%)$ compared to bronchial washing which had sensitivity of $47.6 \%$ and specificity of $71.4 \%$. Similarly, the positive predictive value (PPV), negative predictive value (NPV), false negative index (FNI) and false positive index (FPI) of BB were better in brush samples than washings. The accuracy of BB was 82.8 while that of washing was 57.1 (Table III).

Six (60\%) of the 10 carcinomas diagnosed by washing were morphologically classified as poorly differentiated

Table I: Diagnosis and distribution of various lesions as confirmed on bronchial biopsy

\begin{tabular}{|l|l|}
\hline Diagnosis on bronchial biopsy $(\mathbf{n}=\mathbf{3 5})$ \\
\hline Carcinoma & $\begin{array}{l}21(\mathrm{SCC}=18, \\
\text { Adenocarcinoma }=1, \text { Small } \\
\text { cell carcinoma }=2)\end{array}$ \\
\hline Chronic bronchitis & 3 \\
\hline Lung abscess & 1 \\
\hline Tuberculosis & 5 \\
\hline No significant pathology & 5 \\
\hline
\end{tabular}

Table II: Test results in tabulated form

\begin{tabular}{|l|c|c|c|c|c|}
\hline \multirow{2}{*}{ Sample } & \multicolumn{5}{|c|}{ Test result } \\
\cline { 2 - 6 } & TP & TN & FP & FN & Total \\
\hline Bronchial washing & 10 & 10 & 04 & 11 & 35 \\
\hline Bronchial brushing & 17 & 12 & 02 & 04 & 35 \\
\hline
\end{tabular}


Table III: Comparison of indices of bronchial washings and brush cytology

\begin{tabular}{|l|c|c|}
\hline & WASHING $^{*}$ & BRUSHING \# \\
\hline Sensitivity & 47.6 & 80.9 \\
\hline Specificity & 71.4 & 85.7 \\
\hline PPV & 71.4 & 89.4 \\
\hline NPV & 47.6 & 75 \\
\hline FNI & 52.3 & 19.0 \\
\hline FPI & 28.5 & 14.2 \\
\hline Accuracy & 57.1 & 82.8 \\
\hline
\end{tabular}

${ }^{*}$ The $95 \%$ confidence interval of sensitivity, specificity, negative and positive predictive value is $0.1089,0.1207,0.1207$, and 0.1089 respectively.

\#The $95 \%$ confidence interval of sensitivity, specificity, negative and positive predictive value is $0.085,0.093,0.070$, and 0.1082 respectively.

carcinoma whereas only $8(47 \%)$ out of 17 carcinomas detected by BB were morphologically classified as poorly differentiated carcinoma. On biopsy, 7 (33\%) out of a total of 21 cases were labelled as poorly differentiated carcinoma. Thus morphologic preservation was better in brushing specimens compared to washings.

\section{DISCUSSION}

Bronchoscopy and guided techniques have a definitive role in the diagnosis of endobronchial lesions and a combination of washings and brushings with forceps biopsy have shown to increase the sensitivity from 83.17 to $85.64 \%$ and $90.65 \%$ respectively (1).

Three cases $(8.5 \%)$ of chronic bronchitis showed chronic inflammatory infiltrate and an increase in number of goblet cells on bronchial brushings. Findings on washings were nonspecific whereas bronchial biopsy showed an increase in the number of goblet cells in the lining epithelium, squamous metaplasia and chronic inflammatory cells in the bronchial wall. Similar features were observed on brushing samples carried out on 200 patients with chronic respiratory symptoms (5).

A single case of lung abscess (2.8\%) showed numerous intact and degenerated neutrophils in the necrotic background on brushing and washing. Cell block prepared in this case showed a large amount of necrotic material, bits of lung tissue with intact and degenerated neutrophils. Shroff CP et al. and Tuladhar A et al. found $1.5 \%$ and $13.3 \%$ cases respectively in their series showing features suggestive of an abscess cavity $(5,6)$.

Five cases (14.2\%) were of acid-fast bacillus positive tuberculosis. Bronchial brushings identified only one and in the rest showed chronic inflammatory exudate or granulomatous inflammation. However 3 out of 5 cases were identified by washing. Wallace et al. studied proven cases of tuberculosis and found bronchoscopic specimens to be mostly have a non-specific chronic inflammatory reaction (7). In study by Altaf Bach A et al., bronchial washings smear was positive for acid fast bacilli in 35\% of the cases while caseating granulomas were observed in $16.7 \%$ and were the only diagnostic feature in $13.3 \%$ (8). Daneks, and Bower's and Purohit et al. demonstrated acid fast bacilli in $34 \%$ and $42 \%$ cases respectively whereas in a study by Kulpati et al. $40 \%$ the cases were positive while caseating granulomas were observed in four cases (20\%) and were the only diagnostic feature in $15 \%$ of the patients (9-11).

Out of a total of 35 cases, carcinoma accounted for 21 (60\%). Squamous cell carcinoma was the most common malignancy constituting 18 cases (85.7\%), followed by small cell carcinoma with 2 cases $(9.5 \%)$ and adenocarcinoma in 1 case $(4.7 \%)$ as confirmed by histological examination.

In study by Rawat J et al. on 107 cases, squamous cell carcinoma accounted for 55 cases (51.4\%), adenocarcinoma 12 cases $(11.21 \%)$, large cell carcinoma 4 cases $(3.73 \%)$, unclassified 17 cases (15.88\%) and small cell carcinoma 19 cases $(17.75 \%)(4)$.

In the present study, bronchial brushing identified 17 carcinomas including a case of adenocarcinoma and one case of small cell carcinoma whereas only 10 carcinomas were identified by washing that includes a case of adenocarcinoma.

Comparison of the cytological characters of bronchial brushings (Figure 1) and washings (Figure 2) showed that cellularity of the smear was greater in brush specimens with numerous columnar cells noted against a clear background whereas bronchial washing samples tended to shed mostly single malignant cells with occasional cell clusters which were larger in brush than in washing samples.

Bronchial brushing (Figure 3) showed better cellular preservation, nuclear characteristics, chromatin details and nucleoli compared to washing specimens (Figure 4).

Accuracy was highest in the squamous cell type which was in general agreement with the results of studies conducted by Bedrossian et al. (12). However, Tuladar A et al.found that $\mathrm{BB}$ was the most sensitive technique for diagnosis of small cell carcinoma (80\%) followed by squamous cell carcinoma (35.7\%) (6).

Small cell carcinoma tumor cells showed slight variation in size and shape, high nuclear/cytoplasmic ratio, frequent 
molding, salt and pepper chromatin and crush artefact. Sturgis CD et al. identified nuclear molding and salt and pepper chromatin as important features for distinguishing small cell carcinoma from non- small cell carcinoma (13).

Statistical evaluation in the present 35 cases of bronchopulmonary lesions was carried out to explore the justification of using a cytologic examination as definitive basis upon which to subject the patient to chemotherapy and radiotherapy without histopathological confirmation of the diagnosis.

Bronchial brush cytology was found to have high sensitivity (80.9\%), specificity (85.7\%), PPV (89.4\%), NPV(75\%) and accuracy $(82.8 \%)$ indicating that there were more chances

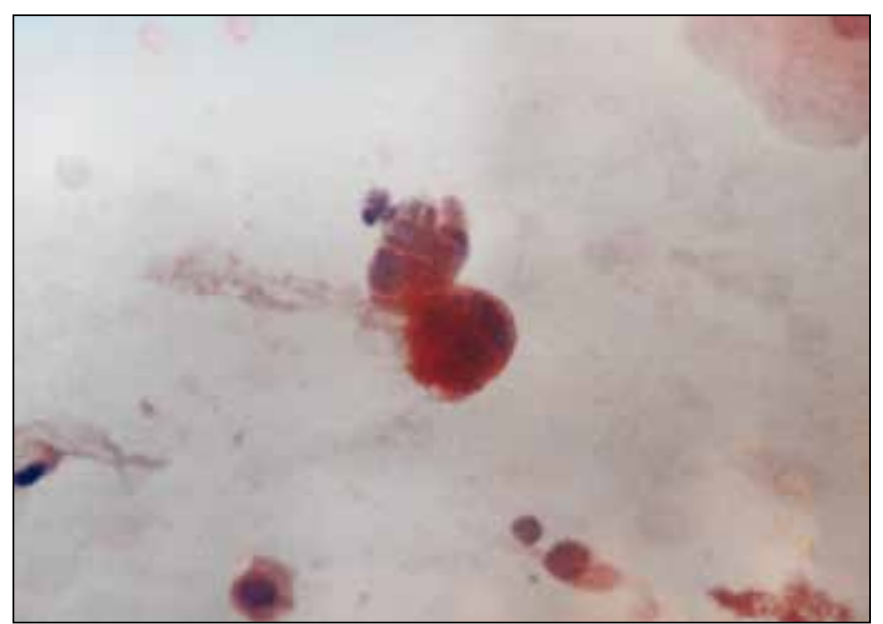

Figure 1: Bronchial brush cytology smear from case of moderately differentiated squamous cell carcinoma shows good cellularity, and better preservation of cellular details (PAP, x100).

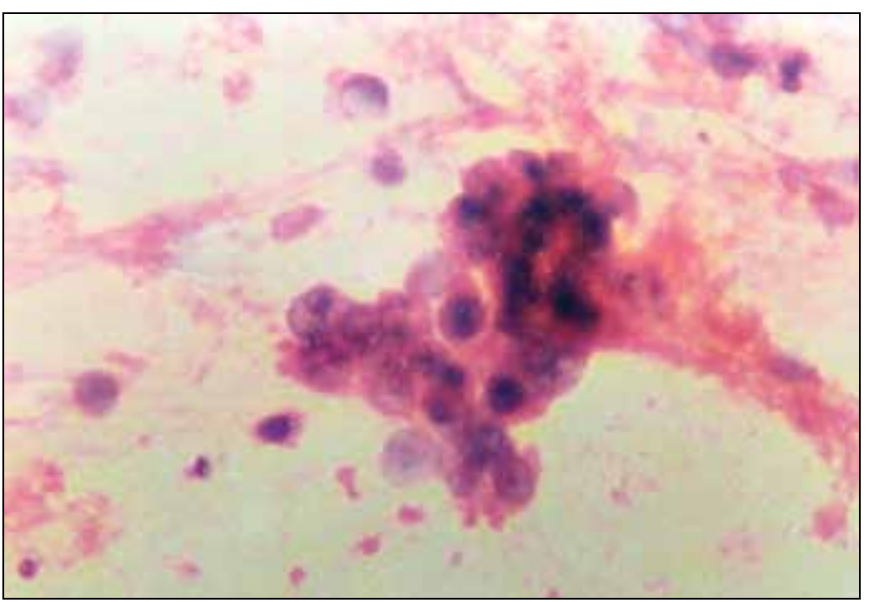

Figure 3: Bronchial brush cytology smear from case of poorly differentiated squamous cell carcinoma shows cluster of cells with crisp nuclear details, coarse chromatin and prominent nucleoli (PAP, $\mathrm{x} 400$ ). of bronchial brush cytologic diagnosis to be correct than that of washings. Similar observations were made by Gaur DS et al. who mentioned sensitivity, specificity, PPV, NPV and accuracy of brushing to be $87.3 \%, 97.6 \%, 95.4 \%$, $93.10 \%$ and $93.90 \%$ respectively (3). Rawat J et al. reported sensitivity of endobronchial brushing to be $69.15 \%$ and that of washing to be $47.66 \%$ (4).

We attempted to confirm with these findings the concept that pulmonary cytology has improved to the point that its sensitivity is high enough to justify its use as a definitive diagnostic tool in those cases where tissue diagnosis is not possible.

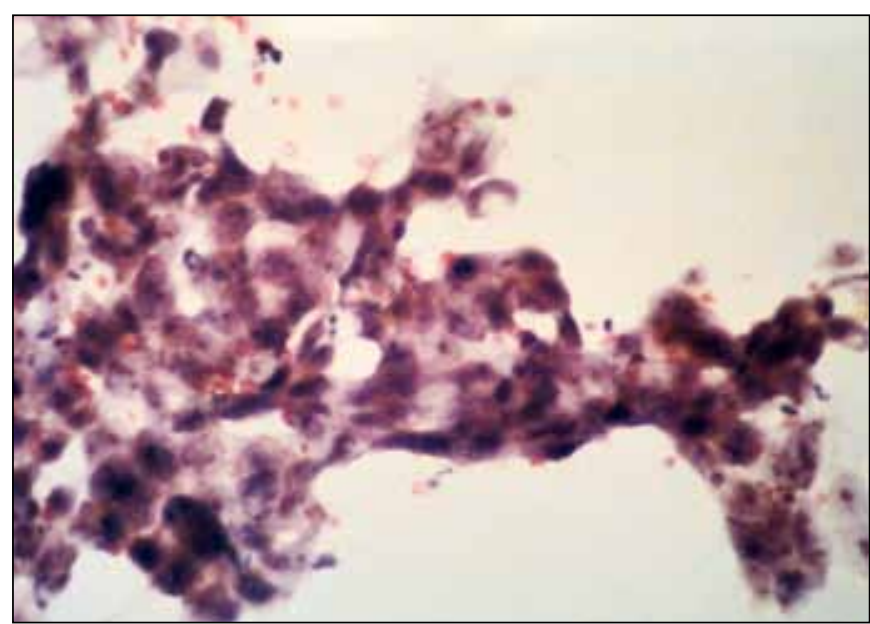

Figure 2: Bronchial washing smear from same case as in figure 1 shows scant cellularity and poorly preserved cellular details (PAP, $\mathrm{x} 100)$.

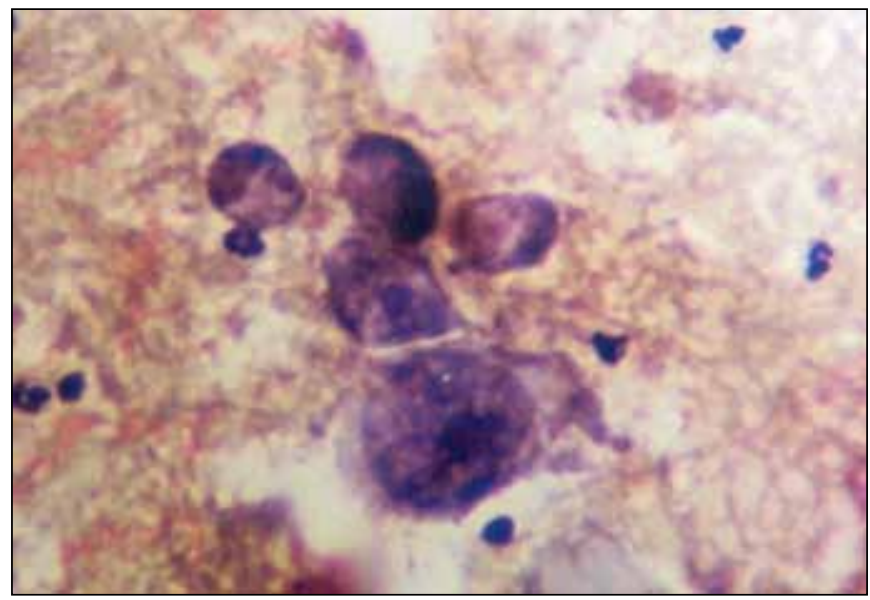

Figure 4: Bronchial washing smear from same case as in figure 3 shows ill defined cellular details (PAP, x400). 


\section{REFERENCES}

1. Karahalli E, Yilmaz A, Türker H, Özvaran K: Usefulness of various diagnostic techniques during fiberoptic bronchoscopy for endoscopically visible lung cancer: Should cytologic examinations be performed routinely? Respiration 2001, 68:611-614

2. Rangdaeng S, Ya-In C, Settakorn J, Chaiwun B, Bhothirat C, Sirivanichai C, Aramratana A: Cytological diagnosis of lung cancer in Chiang Mai, Thailand: cyto-histological correlation and comparison of sensitivity of various methods. J Med Assoc Thai 2002, 85:953-961

3. Gaur DS, Thapiyal NC, Kishore S, Pathak VP: Efficacy of bronchial alveolar lavage and bronchial brush cytology in diagnosing lung cancers. J Cytol 2007, 24:73-77

4. Rawat J, Sindhwani G, Saini S, Kishore S, Kusum A, Sharma $A$ : Usefulness and cost effectiveness of bronchial washing in diagnosing endobronchial malignancies. Lung India 2007, 24:139-141

5. Shroff CP: Abrasive bronchial brushing cytology. A preliminary study of 200 specimens for the diagnosis of neoplastic and nonneoplastic bronchopulmonary lesions. Acta Cytol 1985, 29:101-107

6. Tuladhar A, Panth R, Joshi AR: Comparative analyses of cytohistologic techniques in diagnoses of lung lesions. Journal of Pathology of Nepal 2011, 1:126-130
7. Wallace JM, Deutsch AL, Harrell JH, Moser KM: Bronchoscopy and transbronchial biopsy in evaluation of patients with suspected active tuberculosis. Am J Med 1981, 70:1189-1194

8. Altaf Bachh A, Gupta R, Haq I, Varudkar HG: Diagnosing sputum /smear-negative pulmonary tuberculosis: Does fibreoptic bronchoscopy play a significant role? Lung India 2010, 27:58-62

9. Danek SJ, Bower JS: Diagnosis of pulmonary tuberculosis by flexible fibreoptic bronchoscopy. Am Rev Respir Dis 1979, 119:677-679

10. Purohit SD, Sisodia RS, Gupta PR, Sarkar SK, Sharma TN: Fibreoptic bronchoscopy in the diagnosis of smear negative pulmonary tuberculosis. Lung India 1983, 1:143-146

11. Kulpati DD, Heera HS: Diagnosis of smear negative pulmonary tuberculosis by flexible fibreoptic bronchoscopy. Indian J Tuberc 1986, 33:179-182

12. Bedrossian CWM, Rybka DL: Bronchial brushing during fibreoptic bronchoscopy or the cytodiagnosis of lung cancer: Comparison with sputum and bronchial washings. Acta Cytol 1976, 20:446-453

13. Sturgis CD, Nassar DL, D’Antonio JA, Raab SS: Cytological features useful for distinguishing small cell from non-small cell carcinoma in bronchial brush and washing specimen. Am J Clin Pathol 2000, 114:197-202 